\title{
The parasitic turbellarian Urastoma cyprinae (Platyhelminthes: Urastomidae) from blue mussel Mytilus galloprovincialis in Spain: occurrence and pathology
}

\author{
J. A. F. Robledo ${ }^{1}$, J. Cáceres-Martínez ${ }^{1}$, R. Sluys ${ }^{2}$, A. Figueras ${ }^{1, *}$ \\ ${ }^{1}$ Instituto de Investigaciones Marinas-CSIC, Departamento de Biología y Patología de Organismos Marinos, \\ Eduardo Cabello 6, E-36208 Vigo, Spain \\ ${ }^{2}$ Institute of Taxonomic Zoology, University of Amsterdam, PO Box 4766, 1009 AT Amsterdam, The Netherlands
}

\begin{abstract}
The turbellarian Urastoma cyprinae (Graff, 1882) Graff, 1903 was found inhabiting the mantle cavity between the lamellae of the demibranchs of mussels Mytilus galloprovincialis Lamarck cultured in Galicia (NW Spain). Heavily infested mussels were recognized by the presence of white spots in the gills. The affected area exhibited disarrangement of the gill filaments. The space between 2 lamellae was considerably reduced and the blood sinuses were wider in the unhealthy area than in the healthy area. The turbellarian also induced a heavy infiltration by blood cells and subsequent necrosis of the gill tissues. Routine parasitological studies showed that this parasite was first detected in the Galician region in early 1989. In 1993, U. cyprinae appeared to be present in the 3 main production rias in the Galician region, affecting both natural beds and rafted mussels. $U$. cyprinae could be considered a potential threat to mussel culture
\end{abstract}

KEY WORDS: Urastoma cyprinae Mytilus galloprovincialis $\cdot$ Epidemiology Pathology

\section{INTRODUCTION}

Mussel culture is the most important activity in Galician aquaculture. The annual estimated production is around $200000 \mathrm{t}$ (Figueras 1989). Parasites with the highest frequency in mussels from Galicia are the copepod Mytilicola intestinalis and the protozoan Marteilia sp; however, no mass mortalities have been caused by these parasites (Figueras et al. 1991, Robledo et al. 1992). Lauckner (1983), in his review on molluscan diseases, mentions that turbellarians of the orders Rhabdocoela and Alloeocoela are associated with marine molluscs and that these flatworms normally live in the alimentary tract and in the mantle cavity of bivalves, respectively. Several authors have mentioned the presence of a turbellarian in the intes-

\footnotetext{
- Addressee for correspondence
}

tinal lumen and among the gill filaments of Mytilus galloprovincialis from NW Spain, albeit with very low prevalences and no clear pathology (López et al. 1990, Figueras et al. 1991).

The aim of the present study is to ascertain the specific identity of the flatworm, to describe the pathological effects on the gills of blue mussels, and to document its spreading in the rias of the Galician region.

\section{MATERIALS AND METHODS}

Histological procedures. For identification, the flatworms were killed in Steinmann's fluid or in Clarke's fluid (see Sluys 1989), both fixatives made isotonic to seawater. The animals were preserved in $70 \%$ alcohol. The specimens were stained in borax carmine, after which they were dehydrated in an alcohol series and mounted onto glass slides (Zoologisch Museum Am- 
sterdam, V Pl. $8581 \& 8582$ 2, several whole mounts on 2 slides)

Mussels were flxed whole un Davidson's fixative (Shaw \& Battle 1957) for $24 \mathrm{~h}$ and, subsequently, oblique transverse sections, approximately $5 \mathrm{~mm}$ thıck. were taken from each specimen so that mantle, gonad, digestive gland, gills, kıdney and foot were included. The tissue samples were embedded in paraffin wax and were sectioned at intervals of $5 \mu \mathrm{m}$; sections were stained with uron haematoxylin, acld fuchsin and aniline blue (Gray 1954). For the study of gill damage, gills were removed whole from the mussel and processed as descrubed above. Measurements were taken with a micrometer eyepiece.

Epizootic studies. The epizootic studies were carried out between December 1987 and March 1993 in 3 nas in
NW Spain. Presence of parasites was recorded through (1) examination of the mussels with a dissecting microscope, and (2) preparation of histological slides.

The following experiments were carried out at mussel culture localities (Fig. 1):

Experiment 1: Mussel Mytilus galloprovincialis spat were obtanned from collectors in the rafts at Ría de Vigo. The spat ( 7 to 8 mo old) were placed in baskets on rafts at Melra and Liméns (both in Ría de Vigo). Between December 1987 and March 1990, 30 mussels were collected every month during the first year and bimonthly thereafter.

Experiment 2: Spat (14 mo old) from natural mussel beds were placed in 3 localities, Domayo, Meira and Luméns, and samples were collected bimonthly between January 1989 and December 1990.

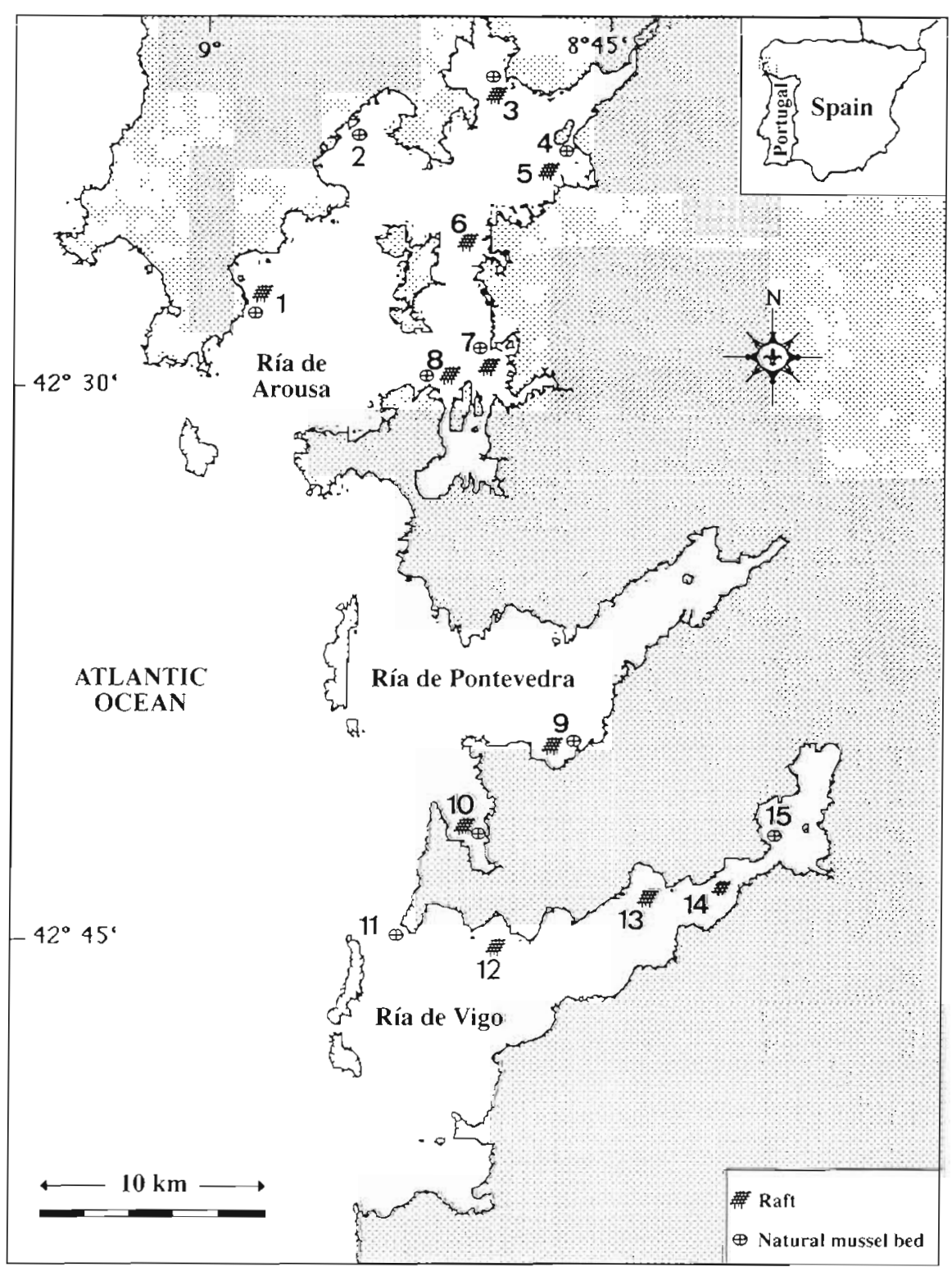

Fig. 1. Map of the Galician rias showing natural mussel beds and rafts. 1, Ribeira; 2, Ribeiriña; 3, Rianxo; 4. Carril; 5, Vilaxoán; 6, Vilanova 7. Cambados; 8, O Grove; 9 , Bueu; 10. Aldán; 11, Cabo Home; 12, Liméns '; 13 , Merra "; 14, Domayo"; 15 , San Adrićn. ("Localities where experiments were carried out) 
Experiment 3: Spat (9 to 10 mo old) from Meira were placed at Liméns and Meira, and spat (of the same age) from Liméns were placed at the same sites. Samples were collected bimonthly between March 1990 and December 1991.

In March 1993, mussels from natural beds and from rafts were collected to record the presence of parasites. The studied areas were Ría de Arousa, Ría de Pontevedra and Ría de Vigo (Fig. 1). Mussels collected from rafts are permanently immersed in water while mussels from natural beds are subjected to tidal cycles.

\section{RESULTS}

\section{The parasite}

The body shape of free-living and swimming worms was vermiform, but while resting on the gills the shape varied between vermiform and spherical (Figs. 2 \& 3). The length of live worms varied between 0.4 and $0.8 \mathrm{~mm}$. Two pigmented eyes near the front end were easily visible. The animals appeared to be not fully mature, but external features and what could be observed of internal structures (pharynx in the most posterior end of the body, a common pore for mouth, male genital duct and female duct at the posterior end, highly developed anterior glands) indicated that the specimens were Urastoma cyprinae (Graff, 1882) Graff, 1903. Several worms were situated within a globular, transparent cocoon, with ample space inside. Specimens of $U$. cyprinae were present in both the inner and outer demibranch of the 4 pairs, between the 2 lamellae and oriented along the gill filaments. Although the flatworms occurred all along the gills, they were most frequent in the middle area. Sometimes the turbellarians (mainly the small ones) were detected swimming freely in the pallial cavity. Table 1 shows the average number of flatworms per sample and the mean number of turbellarians per parasitized mussel from examination with a dissecting microscope; the number of flatworms per sample ranged between 1 and 50 .

In Expt 1 turbellarians were not found. In Expt 2, mussels from all 3 localities were infested by the turbellarian; the prevalence of the parasite at Domayo was the highest $(80 \%)$. The turbellarians were detected macroscopically in August 1990 and histologically in March 1989 samples (Fig, 4A). In Expt 3 Urastoma cyprinae appeared in the macroscopical surveys in August 1990 but histological study showed that it was already present in April 1990. In both years, the highest prevalence was reached in October and December, attaining the observed maximum value of $90 \%$ in December 1991. Examination of histological slides showed that only in July and August 1991 were the mussels free of turbellarians (Fig. 4B).



Fig. 2. Dorsal view of mussel Mytilus galloprovincialis gills showing a white spot with a Urastoma cyprinae (arrow). Scale bar $=1000 \mu \mathrm{m}$

Mussels from rafts examined in March 1993 were all infested, infestation varying between 34.48 and $93.33 \%$. With the exception of Aldán and Bueu in Ría de Pontevedra, samples taken from beds showed few or no parasites and their values were lower than those from rafts (Table 2)

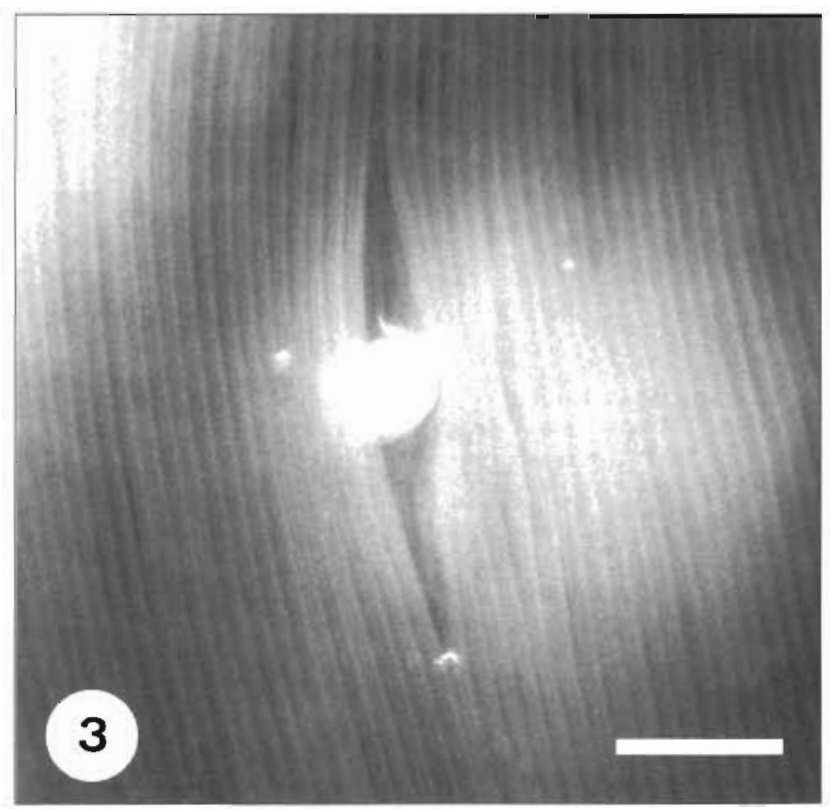

Fig. 3. Mytilus galloprovincialis. Higher magnification of a spot, showing a turbellarian (spherical shape) between the gill filaments. Scale bar $=500 \mu \mathrm{m}$ 
Table 1 Urastoma cyprinae infesting Mytilus galloprovincialıs. Sampling localities ("natural mussel bedi "raft), mussel mean length ( $N$ = number of mussels examined, $\mathrm{SD}=$ standard deviation), percentage of $M$. galloprovincialis infested by $U$. cyprinae, range of turbellarians per sample, and mean number of turbellarians per parasitized mussel in March 1993

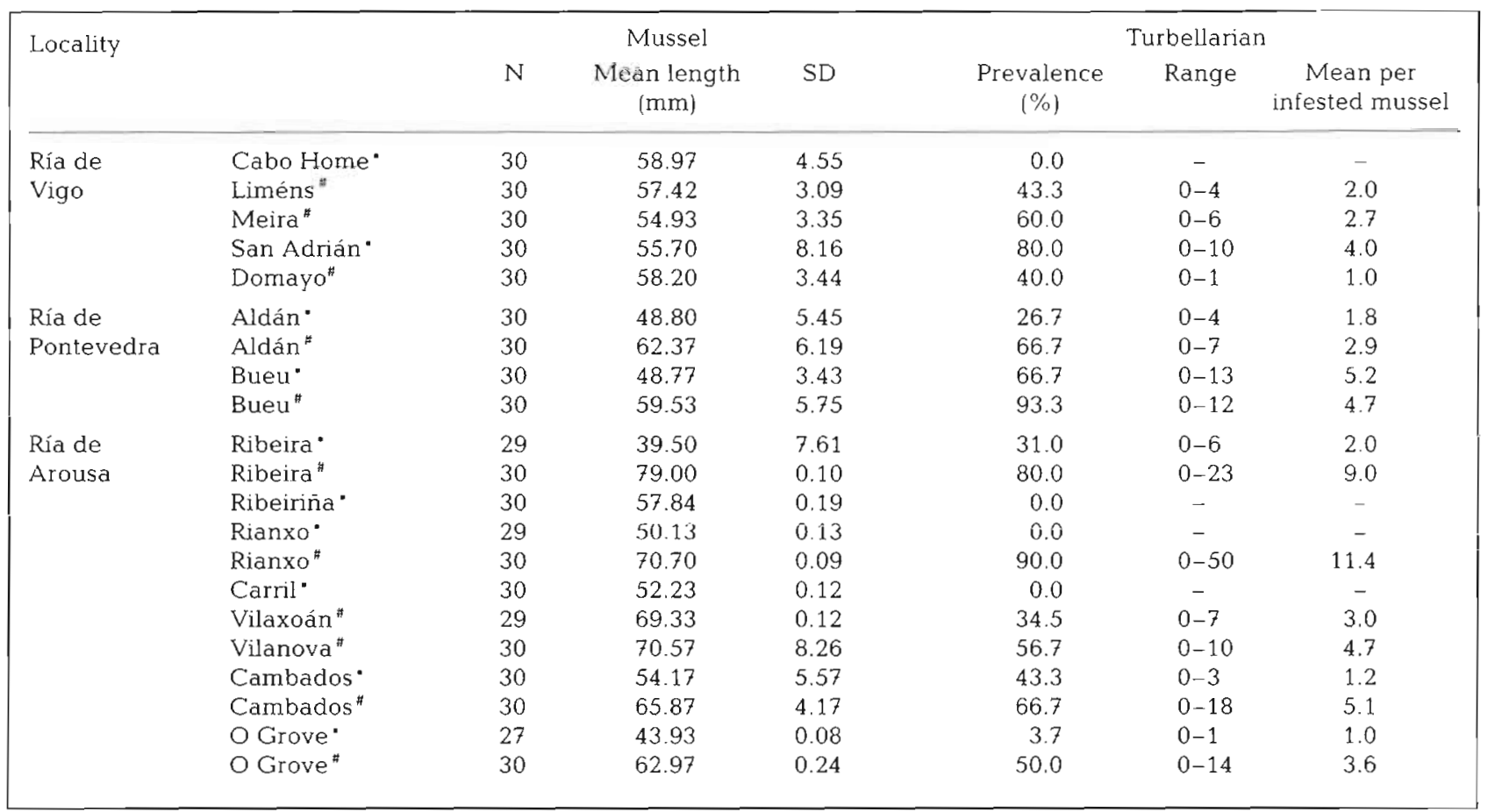

\section{Pathology}

Macroscopic lesions. White or light-coloured spots in the gills were the external signs of Urastoma cyprinae in heavily infested mussels (Fig. 3). The spots were elongated in shape and oriented along the gill filaments; the turbellarian was localized at this point (Fig. 4). Mean length and width of the spot were 1.58 and $1.00 \mathrm{~mm}$, respectively $(\mathrm{SD}=0.41$ and 0.36 , respectively). The number of spots per mussel was less than the total number of turbellarians because the biggest spots contained 4 or 5 flatworms. Some spots were free of turbellarians.

Microscopic lesions. In severely affected areas, the most common lesions were disorganized gill filaments. The space between 2 adjacent filaments (ostium) was considerably reduced in the area surrounding the turbellarian. The blood sinuses were wider in affected areas than in healthy areas, while the former showed haemocytic infiltration (Table 2; Figs. 5, $6 \&$ \&). The epithelial cells of the lamellae were hypertrophied. The infestation elicited a strong host response in that the blood cells were concentrated in the gill filaments and in the area surrounding the parasite (Fig. 8). In areas where the white spots were absent, the only damage observed was compression of gill filaments by the parasite

\section{DISCUSSION}

The turbellarian Urastoma cyprinae has been reported most frequently as being a commensal of one of the following lamellibranchial host species: Mytilus edulis, M. galloprovincialis, Modiola modiolus, Cyprina islandica, Solen vagina, Crassostrea virginica, Tridacna gigas and T. maxima (Dörler 1900, Graff 1913, Westblad 1955, Fleming et al. 1981, Fleming 1986, Goggin \& Cannon 1989, Noury-Sraïri et al. 1990, Murina \& Solonchenko 1991). Furthermore, $U$. cyprinae has also been found free-living among algae or on mud along the Adriatic coast of former Yugoslavia (Westblad 1955). Marcus (1951) described Urastoma evelinae, which was found free-living on algae in the littoral of the Brazilian coast. This author mentioned 6 differences between $U$. cyprinae and $U$. evelinae (the most important one being the fact that the oviducts unite in the former, but remain separated in the latter), but Westblad (1955) synonymized the 2 species, a conclusion followed by Goggin \& Cannon (1989).

Taking into account this synonymization, Urastoma cyprinae has been reported from Australia (Goggin \& Cannon 1989), Brazil (Marcus 1951), the White Sea, the Barents Sea, the Black Sea, the Baltic Sea, the Adriatic Sea (Graff 1913, Westblad 1955, Murina \& Solonchenko 1991), the west coast of Scandinavia 


\section{A. EXPERIMENT 2}

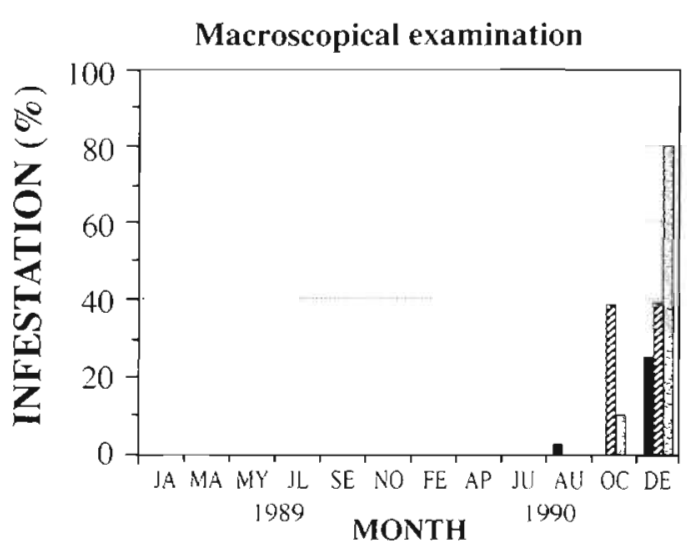

\section{B. EXPERIMENT 3}

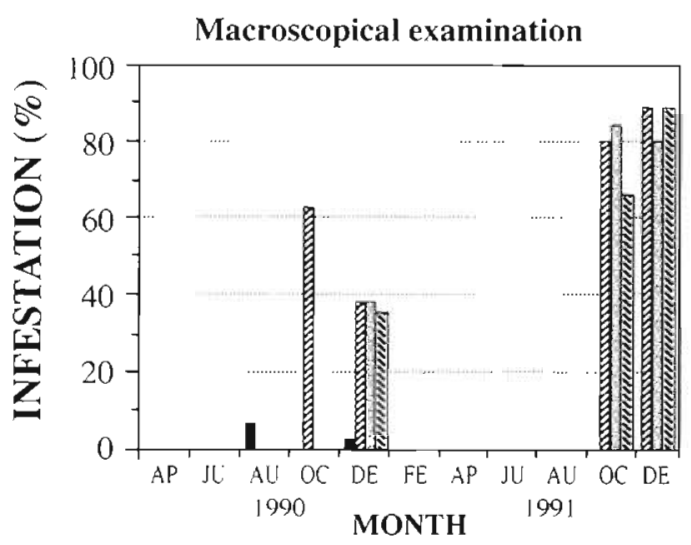

Histological examination

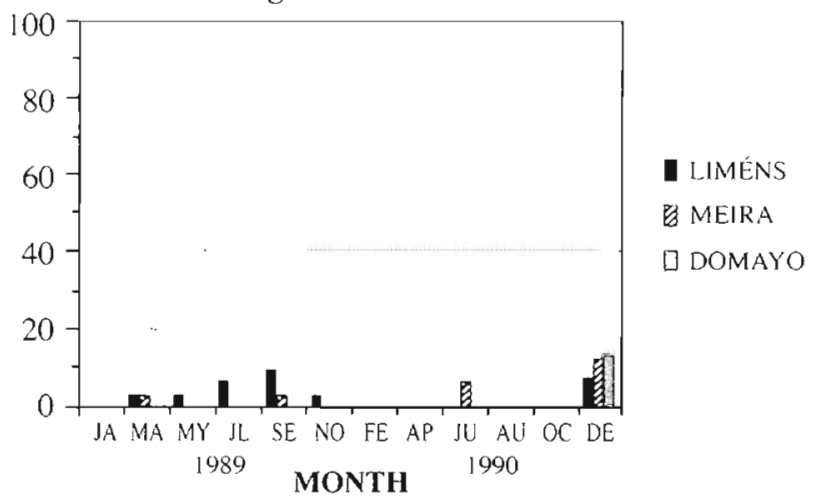

Fig. 4. Mytilus galloprovincialis. Number of specimens of Urastoma cyprinae collected from infested mussels in (A) Expt 2 (Liméns, Meira and Domayo) and (B) Expt 3 (Liméns and Meira). 'Origin of the spat; $\cdot$ location where the spat were placed

(Westblad 1955), the east coast of North America (Fleming et al. 1981, Fleming 1986, Tyler \& Burt 1988) and the French Mediterranean (Noury-Sraïri et al. 1990).

Until the present study, the turbellarian had not been reported from mussels from Galicia. López et al. (1990) reported the presence of unidentified turbellarians with very low prevalence in the intestinal lumen and among the gills of mussels from the

Table 2. Urastoma cyprinae infesting Mytilus galloprovincialis. Mean width $(\mu \mathrm{m})$ of blood sinuses and ostium in healthy and damaged areas of the gills of blue mussels

\begin{tabular}{|lrccc|}
\hline & \multicolumn{2}{c}{ Blood sinuses } & \multicolumn{2}{c|}{ Ostium } \\
& Healthy & Damaged & Healthy & Damaged \\
\hline Minimum & 25.0 & 35.0 & 12.5 & 2.5 \\
Maximum & 30.0 & 92.5 & 20.0 & 7.5 \\
Mean & 26.8 & 53.9 & 17.1 & 5.0 \\
SD & 2.4 & 10.0 & 2.9 & 3.5 \\
& & & & \\
\hline
\end{tabular}

same area but did not find clear pathological effects. In the existing literature, no mention is made of any host reaction or mortalities resulting from infestation by Urastoma cyprinae. However, the results of our study show that $U$. cyprinae causes pathological reactions in its host, the combined effects of which result in disorganization of the gill filaments. Since water pumping rate, and thus feeding capacity, is a function of gill surface area (Jones et al. 1992), the presence of flatworms can greatly reduce feeding capacity in heavily infested mussels. Further experiments must be completed to determine the extent to which gill function is altered, and what effect this has on mussel condition. Gill filament compression by the turbellarian in areas where the white spots were not present may indicate that the worm had recently settled on the host and that a physiological host reaction had not yet been induced. Spots free of turbellarians could indicate that the parasite had caused damage in that area but had abandoned its host or that particular area of the gills. 

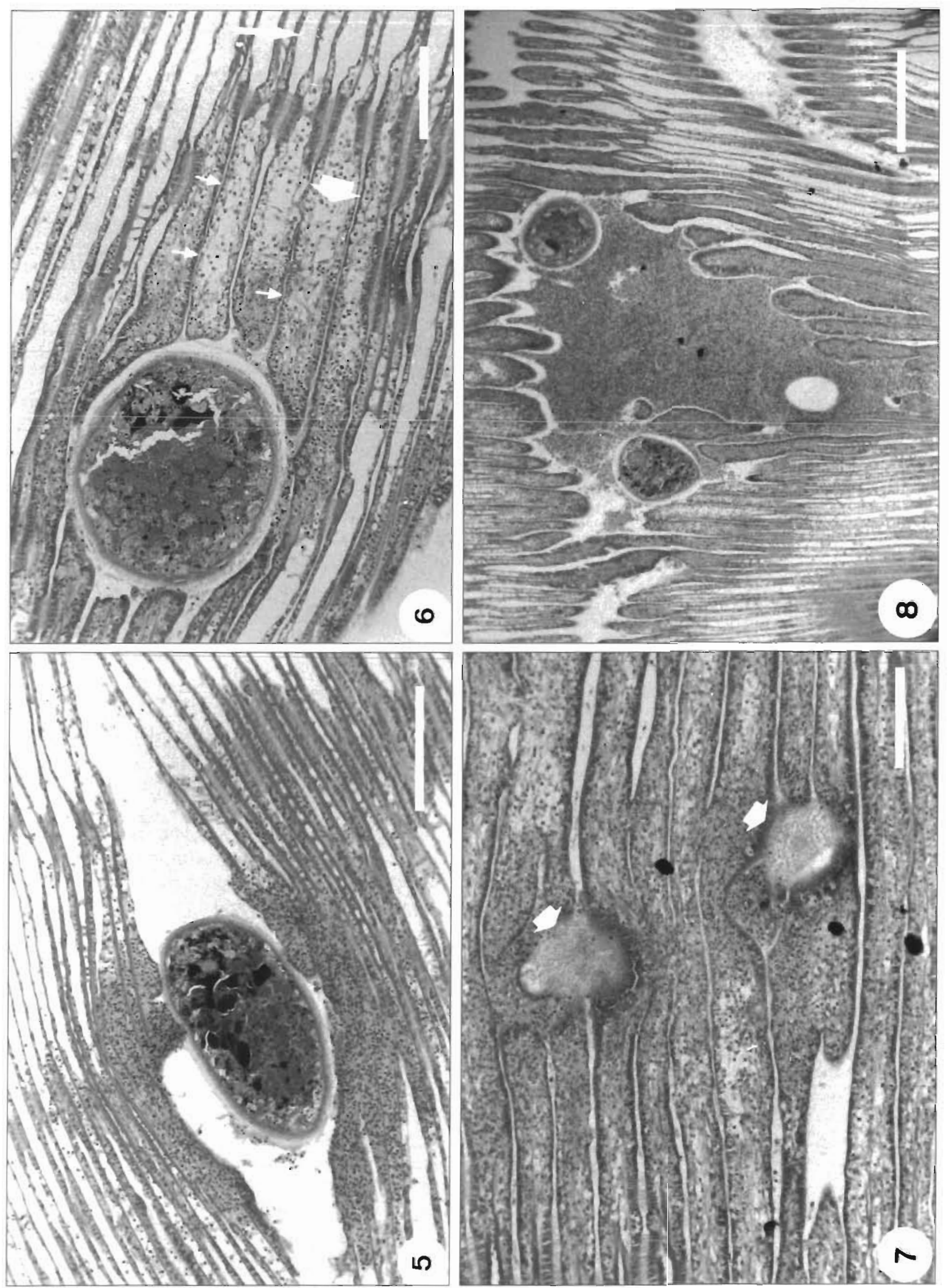
Our observations on the appearance of the worms on their host agree with the study of Noury-Sraïri et al. (1990). These workers reported that the whitish worms are covered by a cocoon of mucus and that animals in situ between the gill filaments have a rounded shape; worms that are freed from their cocoon attained an elongated body form.

Turbellarians were not found in Expt 1. The first detection of Urastoma cyprinae was in March 1989 during the second experiment on mussels from Liméns and Meira. Therefore, the onset of the epizootic can be established as being as early as 1989. Prevalence increased during 1990, with a peak of $90 \%$ in December 1991. Although Expt 1 overlapped with Exp $\mathrm{2}$ during 1989 and part of $1990, U$. cyprinae was not recorded in the first experiment. The absence of $U$. cyprinae infestation at Meira and Liméns during increased presence of the turbellarian in October-December 1991 remains unexplained.

Mussels from both natural beds and rafts in the Galician region were affected by this newly recorded parasite. Mussels taken from beds at Cabo Home, Ribeiriña, Rianxo, Carril and $O$ Grove were free of turbellarians or the parasite was present with very low prevalence, perhaps because of the exposed nature of these localities. This is in agreement with Murina \& Solonchenko (1991), who found a greater number of worms in Mytilus galloprovincialis from silty sand (with a maximum of 170 worms in a mussel) as compared with mussels from a rocky bottom (with a maximum of 7 worms per mussel). Interestingly, mussels taken from natural beds in Aldán and Bueu exhibited high prevalence (26.67 and $66.67 \%$ of mussels parasitized respectively).

In Expts 2 \& 3, the highest prevalence was reached between late autumn and early winter, when water temperature is lower (Cáceres-Martínez et al. 1993). The variation in monthly prevalences suggests an annual cycle with a peak in December. The results obtained in Expt 3 indicate that the parasite's presence was not affected by the origin of the spat because the turbellarians were detected at all localities. Murina \& Solonchenko (1991) found also that in Mytilus galloprovincialis from the Black Sea the highest number of Urastoma cyprinae occurred from midwinter to early spring. These researchers suggested that the rate of infestation shows a seasonal pattern that is directly related to water temperature, lower temperature resulting in a higher prevalence as well as a larger number of worms per mussel. This contrasts strongly with the presence of $U$. cyprinae in the oyster Crassostrea virginica. This host contains large numbers of $U$. cyprinae during the warmer months, and smaller numbers during the colder months; most specimens of the turbellarian probably leave the oyster during the colder months (Fleming 1986). This annual cycle of $U$. cyprinae in $C$. virginica is caused by the life cycle of the host, since the oyster is unable to feed at temperatures below $5^{\circ} \mathrm{C}$ and closes its shell from November to April (Fleming 1986).

Heavily infested mussels can be recognized by the presence of white or coloured spots in the gills. However, when the parasite is very young its presence can be detected only in histological preparations. The differences found between the macroscopic and microscopic surveys suggest that histological analysis is a technique well suited to describe and assess the effects of Urastoma cyprinae on mussel gills. However, for a correct estimation of the number of parasites per host, histological studies should be done on all the gills.

Further studies are being conducted in order to understand the biological cycle and the annual cycle of the worm in the Galician region and their effect on mussel physiology. Greater knowledge of Urastoma cyprinae in blue mussels could give us the reason why the mussel was not infested before in this area and if management measures could be taken to prevent the presence of the turbellarian in the uninfected mussel culture areas.

Acknowledgements. J.A.F.R. acknowledges the Diputacion de Pontevedra, Spain, and Xunta de Galicia, for his research fellowship in the IIM-CSIC. J.C.M. was supported by a grant of the CONACyT from Mexico. Dr L. R. G. Cannon (Queensland Museum, Brisbane) is thanked for his advice on the identification of the species. We thank J. R. Caldas for technical assistance.

\section{LITERATURE CITED}

Cáceres-Martínez, J., Robledo, J. A. F., Figueras, A. (1993). Influencia de factores ambientales en la fijación del mejillón (Mytilus galloprovincialis) de Galicia. Actas III Congr. nac. Acuicult. 377-382

Figs. 5 to 8. Urastoma cyprinae infesting Mytilus galloprovincialis. Fig. 5 . The first lesions observed at the beginning of the infestation, viz. gill filament compression and infiltration of blood cells. Scale bar $=200 \mu \mathrm{m}$. Fig. 6 . Paraffin section of a U. cyprinae in the gills of its host showing the disorganization of this organ in the area surrounding the worm. Note the swelling of the gill characterized by the reduced space between 2 adjacent filaments (small arrows) and the enlarged blood sinuses (wide arrow) in comparison with the healthy area (large thin arrow). Scale bar $=200 \mu \mathrm{m}$. Fig. 7. Detail of the avanced stage of infestation, with heavy infiltration and disorganization of the gills caused by the worm's presence (arrows). Scale bar $=200 \mu \mathrm{m}$. Fig. 8 . Histological section of a spot containing several worms. Note the heavy infiltration of blood cells around the turbellarians. Scale bar $=500 \mu \mathrm{m}$ 
Dörler, A. (1900). Neue und wenig bekannte rhabdocöle Turbellarien. Z. wiss, Zool 68: 1-42

Figueras, A. J. (1989). Mussel culture in Spain and France. World Aquacult. 20(4): 8-17

Figueras, A. J., Jardón, C. F., Caldas, J. R. (1991). Diseases and parasites of rafted mussels (Mytilus galloprovincialis): preliminary results. Aquaculture 99: 17-33

Fleming, L. C. (1986). Occurrence of symbiotic turbellarians in the oyster Crassostrea virginica. Hydrobiologia 132: 311-315

Fleming, L. C., Burt, M. D. B., Bacon, G. B. (1981). On some commensal Turbellaria of the Canadian east coast. Hydrobiologia 84 : 131-137

Goggin, C. L., Cannon, L. R. G. (1989). Occurrence of a turbellarian from Australian tridacnid clams. Int. J. Parasitol. 19: $345-346$

Graff, L. von (1913). Platyhelminthes. Turbellaria. II. Rhabdocoelida. In: Schulze, F. E. (ed.) Das Tierreich. Eine Zusammenstellung und Kennzeichnung der rezenten Tierformen. 35. Lieferung. Friedlander, Berlin

Gray, P. (1954). The microtomists formulary and guide. Blakiston, New York: p. 749

Jones, H. D., Richards, O. G., Southern, T. A. (1992). Gill dimensions, water pumping rate and body size in the mussel Mytilus edulis L. J. exp. mar. Biol. Ecol. 155: $213-237$

Lauckner, G. (1983). Diseases of Mollusca: Bivalvia. In: Kinne, O. (ed.) Diseases of marine animals, Vol. II, Introduction, Bivalvia to Scaphopoda. Biologische Anstalt Helgoland, Hamburg, p. 630-632

López, M. C., Carballal, M. J., Mourelle, S. G., Villalba, A., Montes, J. (1990). Parasites and diseases of mussels

Responsible Subject Editor: A. K. Sparks, Seattle, Washington, USA
Mytilus galloprovincialis Lmk, from estuaries of Galicia. In: Figueras, A. (ed.) Abstracts 4th. int. Colloq. Pathol. Mar Aquac. September 1990 Vigo (Spain), 105

Marcus, E. (1951). Turbellaria Brasileiros 9. Bol. Fac. Fil. Ciênc. Letr., Univ. Sảo Paulo, Zool. 16: 5-215

Murina, G.-V., Solonchenko, A. I. (1991). Commensals of Mytilus galloprovincialis in the Black Sea: Urastoma cyprinae (Turbellaria) and Polydora ciliata (Polychaeta). Hydrobiologia 227: 385-387

Noury-Srairi, N., Justine, J.-L., Eucet, L. (1990). Ultrastructure du tegument et des glandes sous-epithéliales de Urastoma cyprinae (Prolecithophora), turbellarie parasite de mollusque. Annls Sci. nat. Zool. 11: 53-71

Robledo, J. A. F., Puentes, C. F., Santarém, M. M., Novoa, B., Cáceres, J., Figueras, A. (1992). Epizootilogical study and assessment of the effects of the infections by Marteilia sp. on the condition index and the gonadal development of mussels Mytilus galloprovincialis Lmk experimentally cultured in Ría de Vigo (NW of Spain). In: Vivares, C. P. (ed.) Abstracts 5th int. Colloq. Pathol. Mar. Aquac. BIOCIM, April 1992, Montpellier (France), 65

Shaw, B. L., Battle, H. I. (1957). The gross microscopic anatomy of the digestive tract of the oyster Crassostrea virginica (Gmelin). Can. J. Zool. 35: 325-346

Sluys, R. (1989). A monograph of the marine triclads. A. A. Balkema, Rotterdam

Tyler, S., Burt, M. D. B. (1988). Lensing by a mitochondrial derivative in the eye of Urastoma cyprinae (Turbellaria, Prolecithophora). Prog. Zool. 36: 229-234

Westblad, E. (1955). Marine 'Alloeocoels' (Turbellaria) from North Atlantic and Mediterranean coasts. I. Arkiv för Zoologi 7: 491-526

Manuscript first received: January 5, 1993

Revised version accepted: November 5, 1993 